T. ISHIKURA ${ }^{1}$

\title{
RELATIONSHIP BETWEEN THE REACTION TIME AND EEG PARAMETERS DURING JUDGMENTS ON THE CORRESPONDENCE OF DELAYED OR SIMULTANEOUSLY PRESENTED IMAGES OF TWO MODELS
}

\begin{abstract}
Received November 12, 2014
This study examined how judging whether the poses of two figures are the same in tasks with delayed and simultaneous image presentation affects the participants' reaction times and electroencephalograms (EEGs). Eighteen university students performed a delayed task, in which an image of a doll was first presented for $3 \mathrm{sec}$ followed by a second image of the doll, and a simultaneous task, in which images of two dolls were presented on the left and right sides of the monitor at the same time. The dolls were shown from the front and rear angles. The participants were instructed to judge whether the images were the same as accurately and quickly as possible, and the reaction times were recorded. EEG signals were recorded from Fp1, Fp2, F3, F4, C3, C4, P3, and P4. The reaction times in the delayed task were found to be shorter those in the simultaneous task, and that these times for the $0^{\circ}$ condition were shorter than for the $180^{\circ}$ condition. The amplitudes of EEG responses at Fp1 and Fp2 were larger than those at other electrodes, and that responses in the right hemisphere during the $180^{\circ}$ condition and the delayed task within the $\alpha 1$ frequency band were smaller than the responses at other electrodes. These results indicate that cerebral activity in the frontal region of the right hemisphere is associated with the judgment of correspondence or non-correspondence in spatial compatibility tasks.
\end{abstract}

Keywords: visual perception, spatial correspondence, judgment, viewing angle, electroencephalography.

\section{INTRODUCTION}

When a learner attempts to imitate the movement of a $3 \mathrm{D}$ image of the demonstrator, the extent of spatial compatibility between the bodies of a demonstrator and learner and the timing of observations affects the speed at which the response movement can be reproduced [1]. Ishikura and Inomata [2] reported that, compared to viewing a model from the front, viewing an observed model from the rear increased the speed with which the demonstrator's movement could be reproduced. They also proposed [2] that the reason for such results was that the learner who observes the demonstrator from the front angle has to process the rotation of the demonstrator's image because there was a difference of $180^{\circ}$ between the physical position of the demonstrator and that of the

Faculty of Sports Science and Health, Doshisha University, Kyotanabe, Kyoto, Japan.

Correspondence should be addressed to T. Ishikura

(e-mail: tishikur@mail.doshisha.ac.jp). learner. Shepard and Metzler [3] reported that when participants are required to judge the correspondence or non-correspondence of two 3D objects presented at several different orientations, the reaction time for these judgments became greater as the degree of difference between the two objects increased. This phenomenon has been called mental rotation, and it was assumed that the representation of the character (e.g., letter, geometrical figure, etc.) is rotated mentally in a continuous way [4].

On the other hand, timing of presentation of the movement for the learner, with regards to whether they observe the demonstration before, during, or after reproducing the performance, contains elements that affect the rate of reproduction upon imitation of the demonstrator's movements (e.g., $[5,6])$. Weeks et al. [5] reported that the participants performed better the respective operations at delayed observation than at simultaneous one, because the delayed observation condition required a cognitive effort during acquisition, compared to the simultaneous condition. 
These reports might suggest that the correspondence between the body locations of the learner and demonstrator and timing of observation during imitation affect the learner's cognitive loading and the efficiency of movement reproduction. In studies examining the relationship between the cognitive loading of visual imagery and brain activation, it was reported that the frontal and parietal regions of the brain were activated when participants had to mentally rotate or invert from left to right the direction of a visual object [7]. Additionally, it was shown that different parts of the brain were activated when the participants observed the movement before or while performing the movement (e.g., $[8,9]$ ).

The aim of our study was to examine the timing of observation and the congruence judgments of participants when observing the poses of two 3D models. This study sought to investigate the effects these judgments might have on the cognitive load by measuring the relationship between the reaction times of the judgments and the EEG waves occurring at different cortical sites during the judgment (cortical responses). The hypotheses were based on results of the previous study. Specifically, it was hypothesized that the reaction times at a zero angle of the difference condition would be shorter than these times for $180^{\circ}$ condition. Furthermore, it was predicted that the reaction times during delayed presentation would be shorter than those during simultaneous presentation. Because processing of spatial manipulations (e.g., mental rotation) and retaining an image (e.g., a doll's posture) are related to brain activation, it was predicted that the amplitudes of responses recorded over the frontal (Fp1, Fp2, F3, and F4) and parietal (P3 and $\mathrm{P} 4)$ regions to judgments under $180^{\circ}$ conditions would be higher than those recorded to judgments under $0^{\circ}$ condition.

\section{METHODS}

Participants. Eighteen healthy university students, 9 man and 9 women, age $20.3 \pm 1.1$ years (mean \pm s.d.) participated in this experiment.

Tasks, Materials, and Design. First, all participants closed their eyes for $3 \mathrm{~min}$ (the eye-closing phase). Next, half of the participants performed the delayed task first and then performed the simultaneous task, while the other half first performed the simultaneous task followed by the delayed one. In the delayed task, images of a front or back view (rotated at $0^{\circ}$ and $180^{\circ}$,

respectively) of a wooden jointed doll were presented on a computer monitor for $3 \mathrm{sec}$ as the base stimulus, and then a second image of the doll was presented in the same or a different pose at either the same or a different angle. In the simultaneous task, the front or back view (rotated $0^{\circ}$ and $180^{\circ}$, respectively) of a doll was presented on the left side of a computer monitor. The respective image was simultaneously presented in the same or different pose on the right side of the monitor at either the same or different angle. The participants were required to judge as quickly as possible whether the poses were the same in both tasks (Fig. 1). Each participant judged 72 trials for each task (delayed and simultaneous), and the poses matched in half of the trials.

EEG Recordings. EEG leads were placed according to the international 10-20 electrode system. Signals were recorded from sites Fp1, Fp2, F3, F4, C3, C4, P3, and $\mathrm{P} 4$ with referential derivation using an electrode cap (Electro-Cap International, USA). The reference electrode was placed on the earlobe (auricular). EEGs were sampled at $500 \mathrm{sec}^{-1}$ using an EEG-1200 system (Nihon Kohden, Japan), and data were subjected to $0.15-60-\mathrm{Hz}$ band-pass filtering. The impedance of all

A
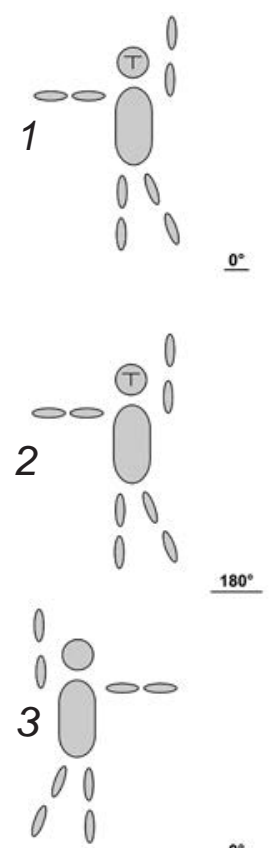

F i g. 1. Examples of the poses of the test object used in the experiment. A) Samples of the poses and angle differences; B) samples of the simltaneous and delayed tasks.

Р и с. 1. Приклади поз тест-фігури, використані в експерименті. 
electrodes was $10 \mathrm{k} \Omega$ or less.

Data Processing. The reaction times and EEG data were compared when the angle of difference between the two doll images was $0^{\circ}$ and $180^{\circ}$. The data were subjected to frequency analysis by conducting 256-point fast Fourier transforms using ATAMAP II (Kissei Comtec, Japan). For the eye-closing phase, the raw data were analyzed at a resolution of $1.95-\mathrm{sec}^{-}$ ${ }^{1}$; three $0.51-\mathrm{sec}$ units were averaged to yield a $1.54-$ sec epoch for analysis. Data acquired during judgment were also analyzed at a resolution of $1.95-\mathrm{sec}^{-1}$, but only single 0.51 -sec units were analyzed. Moreover, since the time for judgment was short, the raw data were acquired three times during each phase, from the stimulus presentation to response. For analysis of the EEG data, we compared the averages of three raw data sets.

The potential remainders were found for each EEG frequency range during the eye-closing phases and the judgment phase. The frequency bands were $\alpha 1$ $(8-10 \mathrm{~Hz}), \alpha 2(10-13 \mathrm{~Hz}), \beta 1(13-20 \mathrm{~Hz})$, and $\beta 2$ $(20-30 \mathrm{~Hz})$. That is, the remainders were positive values if the potentials during the judgment phase were greater than they were during the eye-closing phase. If the potentials during the judgment phase were lower than those during the eye-closing phase, then the remainder was a negative value.

Dependent Variables and Statistical Analyses. The reaction time for judgment and the remainders of the EEG potentials between the eye-closing and the judgment phases in the delayed task or simultaneous one $(\mu \mathrm{V})$ at the Fp1, Fp2, F3, F4, C3, C4, P3, and P4 electrodes were used as dependent variables.

A two-way analysis of variance (ANOVA) and three-way ANOVA were used in the study. All significant effects are reported at $P<0.05$ with the effect sizes reported as $\eta^{2}$ and the statistical power reported as $\phi$. Post-hoc comparisons of the means were performed using the Tukey HSD techniques. The Pearson correlation analysis with a two-tail test was used to examine the relationships between the reaction time and brain waves. IBM SPSS Version $22 \mathrm{~J}$ (IBM SPSS Japan, Japan) statistical software was used for all statistical analyses.

\section{RESULTS}

Percentage of Correct Responses. Participants were instructed to respond as quickly as possible and with minimum keeping errors. On average, only $3.2 \%$ of

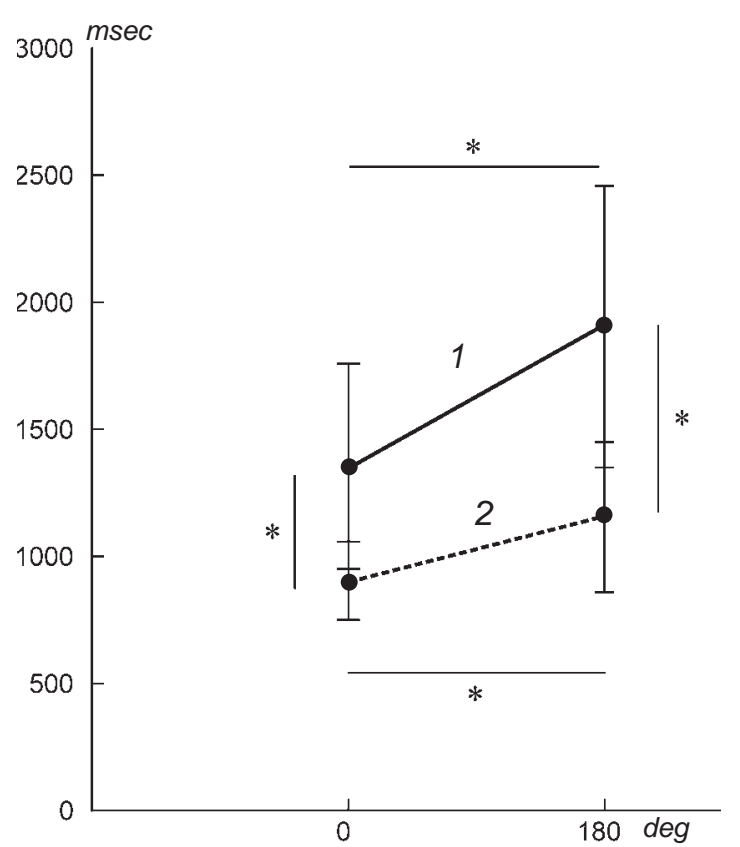

F i g. 2. The response times for the delayed (1) and simultaneous (2) tasks. $* P<0.05$ in the comparisons shown.

Р и с. 2. Значення часу відповіді в «затриманому» та «одночасному» завданнях.

the responses were incorrect (ranging from 0.6 to $5.7 \%$ for individual participants).

Reaction Times. A task (delayed or simultaneous) $\times$ $\times$ angle of difference $\left(0^{\circ}\right.$ or $\left.180^{\circ}\right)$ two-way ANOVA was performed. Figure 2 shows the means and s.d. of the reaction times in both tasks. The results showed that the main effect of the task was significant $\left(F_{1,17}=\right.$ $\left.=42.07, P=0.01, \eta^{2}=0.71, \phi=1.00\right)$, and that the reaction time in the delayed task was shorter than that in the simultaneous task. In addition, the main effect for the angle of difference was significant $\left(F_{1,17}=66.71, P=0.01, \eta^{2}=0.80, \phi=1.00\right)$. Tests for multiple comparisons showed that the reaction times for the $0^{\circ}$ condition were shorter than those for the $180^{\circ}$ condition. A significant interaction effect also emerged $\left(F_{1,17}=18.41, P=0.01, \eta^{2}=0.52, \phi=0.98\right)$. Specifically, the reaction times for the $0^{\circ}$ condition were smaller than those for the $180^{\circ}$ condition in both tasks, and the reaction times in the delayed task were shorter than those in the simultaneous task for both angles of difference $\left(0^{\circ}\right.$ and $\left.180^{\circ}\right)$.

EEG During the Judgment Phase. A task (delayed or simultaneous $) \times$ angle of difference $\left(0^{\circ}\right.$ or $\left.180^{\circ}\right) \times$ $\times$ electrode site $(\mathrm{Fp} 1, \mathrm{~F} 3, \mathrm{C} 3, \mathrm{P} 3, \mathrm{Fp} 2, \mathrm{~F} 4, \mathrm{C} 4$, or P4) three-way ANOVA was performed for each 

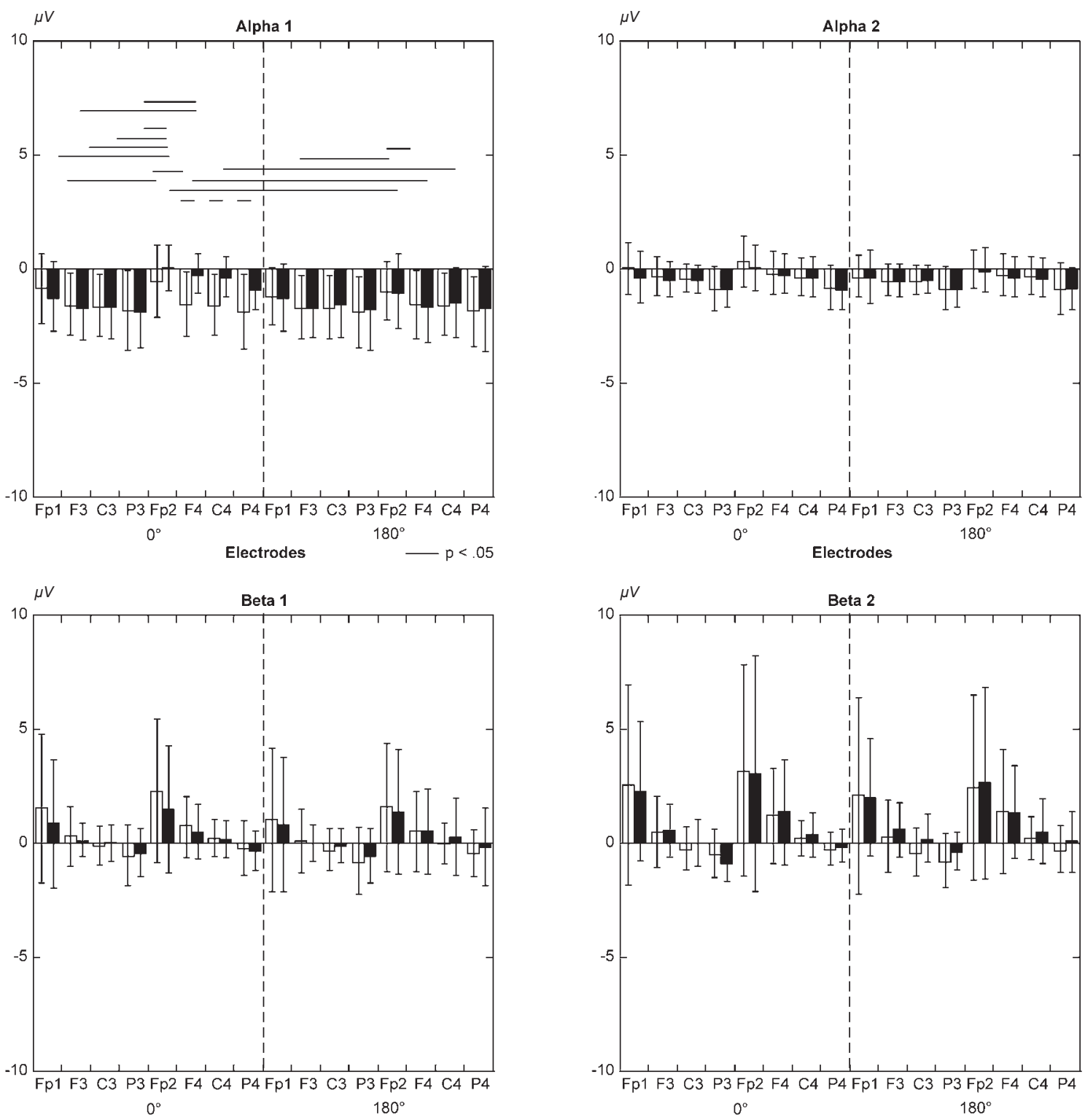

F i g. 3. Potential remainders, $\mu \mathrm{V}$, for each electrode at the difference of angle for each frequency band. Electrodes were Fp1, Fp2, F3, F4, $\mathrm{C} 3, \mathrm{C} 4, \mathrm{P} 3$, and P4; frequency bands were $\alpha 1(8-10 \mathrm{~Hz}), \alpha 2(10-13 \mathrm{~Hz}), \beta 1(13-20 \mathrm{~Hz})$, and $\beta 2(20-30 \mathrm{~Hz})$. Open and filled columns, for the delayed and simultaneouse task, respectively.

Р и с. 3. Різниці амплітуд (мкВ), котрі пов’язані з різницями кута представлення зображень, для аналізованих ЕЕГ-субритмів, відведених кожним із електродів.

above-mentioned frequency band $(\alpha 1, \alpha 2, \beta 1$, and $\beta 2$ ). Figure 3 shows the means and s.d. of the amplitudes for each frequency band. Within the $\alpha 1$ range, there was a significant main effect for the angle of difference $\left(F_{1,17}=11.15, P=\right.$ $\left.=0.01, \eta^{2}=0.40, \phi=0.88\right)$, with the responses for the $0^{\circ}$ condition being larger than those for the $180^{\circ}$ condition $\left(0^{\circ}>180^{\circ}\right)$. There was also a significant main effect of the electrode location $\left(F_{7119}=6.45\right.$, $\left.P=0.01, \eta^{2}=0.28, \phi=1.00\right)$. Post-hoc tests $(P<$ $<0.05)$ showed that the amplitudes of the responses at Fp2 were higher than those at Fp1, F3, C3, and F4 (Fp2 > Fp1, F3, C3, and F4), and that the response amplitudes at F3 were smaller than those at F4 and P4 (F3 < F4 and P4). The task $\times$ electrode interaction was significant $\left(F_{7,119}=6.91, P=0.01, \eta^{2}=0.29, \phi\right.$ 
Table 1. Pearson correlation coefficients between the reaction times and EEG response ampletudes for four frequency bands at each electrode.

Коефіціети кореляції Пірсона для значень часу реакції та амплітуди ЕЕГ-відповідей у кожному з відведень для чотирьох частотних діапазонах.

\begin{tabular}{|c|c|c|c|c|c|c|c|c|c|c|}
\hline & \multirow{2}{*}{\multicolumn{2}{|c|}{ Electrode }} & \multicolumn{4}{|c|}{ Delayed task } & \multicolumn{4}{|c|}{ Simultaneous task } \\
\hline & & & $\underline{\underline{0}}$ & & 18 & & $\underline{0}$ & & & \\
\hline \multirow{4}{*}{ Alpha 1} & $\mathrm{Fp} 1$ & $\mathrm{Fp} 2$ & -.01 & -.06 & .05 & .07 & .31 & .20 & $.52 *$ & $.49 *$ \\
\hline & F3 & F4 & .05 & .05 & .12 & .13 & .30 & .25 & .39 & .40 \\
\hline & $\mathrm{C} 3$ & C4 & .09 & .06 & .21 & .19 & .29 & .22 & 37 & .32 \\
\hline & $\mathrm{P} 3$ & $\mathrm{P} 4$ & -.04 & .13 & .02 & .29 & .03 & -.04 & .11 & .15 \\
\hline \multirow{4}{*}{ Alpha 2} & $\mathrm{Fp} 1$ & $\mathrm{Fp} 2$ & -.23 & -.38 & -.27 & -.31 & .16 & -.07 & .22 & .12 \\
\hline & F3 & F4 & -.40 & -.43 & -.31 & -.26 & -.11 & -.26 & -.18 & -.16 \\
\hline & C3 & C4 & -.38 & -.27 & -.18 & -.14 & -.14 & -.26 & -.10 & -.28 \\
\hline & P3 & P4 & -.27 & -.04 & -.06 & .11 & -.11 & -.44 & -.07 & -.16 \\
\hline \multirow{4}{*}{ Beta 1} & $\mathrm{Fp} 1$ & $\mathrm{Fp} 2$ & -.19 & -.11 & -.06 & .01 & .17 & .03 & .37 & .36 \\
\hline & F3 & $\mathrm{F} 4$ & -.06 & .03 & -.01 & .12 & -.03 & -.18 & .19 & .19 \\
\hline & $\mathrm{C} 3$ & $\mathrm{C} 4$ & .11 & -.17 & .14 & .01 & -.22 & -.39 & -.08 & .10 \\
\hline & P3 & P4 & .12 & -.10 & .09 & .07 & -.06 & -.39 & .05 & .07 \\
\hline \multirow{5}{*}{ Beta 2} & $\mathrm{Fp} 1$ & $\mathrm{Fp} 2$ & -.03 & .10 & -.12 & .08 & .08 & -.01 & .28 & .31 \\
\hline & F3 & F4 & .04 & .08 & -.03 & .04 & -.16 & -.26 & -.10 & .03 \\
\hline & $\mathrm{C} 3$ & $\mathrm{C} 4$ & .21 & .15 & .14 & .01 & -.27 & $-.47 *$ & -.36 & -.06 \\
\hline & P3 & P4 & .11 & .24 & -.05 & .03 & -.30 & $-.61 * *$ & -.31 & -.04 \\
\hline & & & & & & $f=18$ & ** & $p<.01$ & & $\overline{<.05}$ \\
\hline
\end{tabular}

$=1.00)$. Multiple comparison tests showed that the amplitudes of the responses recorded in the delayed task were longer than those of the responses recorded in the simultaneous task at F4, C4, and P4 (delayed < $<$ simultaneous at F4, C4, and P4). In the delayed task, the response amplitudes at $\mathrm{Fp} 2$ were larger than those at F3, C3, and F4 (Fp2 > F3, C3, and F4 in the delayed task). In the simultaneous task, the response amplitudes at $\mathrm{Fp} 2$ were higher than the amplitudes at $\mathrm{Fp} 1, \mathrm{~F} 3$, and $\mathrm{C} 3$ (Fp2 > Fp1 and F3 in the simultaneous task), and the respective amplitudes at $\mathrm{F} 4$ and $\mathrm{C} 4$ were greater than those at $\mathrm{F} 3(\mathrm{~F} 4$ and $\mathrm{C} 4>\mathrm{F} 3$ in the simultaneous task). The angle of difference $\times$ electrode interaction was significant $\left(F_{7.119}=6.91, P=0.01, \eta^{2}=\right.$ $=0.29, \phi=1.00)$. The amplitudes of the responses under $0^{\circ}$ condition were higher than the respective indices of the responses under $180^{\circ}$ condition at $\mathrm{Fp} 2, \mathrm{~F} 4, \mathrm{C} 4$, and $\mathrm{P} 4\left(0^{\circ}>180^{\circ}\right.$ at $\mathrm{Fp} 2, \mathrm{~F} 4, \mathrm{C} 4$, and $\mathrm{P} 4)$. Multiple comparisons tests for the $0^{\circ}$ condition showed that the response amplitudes at $\mathrm{Fp} 2$ were greater than the amplitudes at Fp1, F3, C3, P3, and P4 (Fp2 > Fp1, F3, C3, P3 and P4 for the $0^{\circ}$ condition), and that the amplitudes at F4 were higher than those at F3 $\left(\mathrm{F} 4>\mathrm{F} 3\right.$ at $\left.0^{\circ}\right)$. For the $180^{\circ}$ condition, the response amplitudes at $\mathrm{Fp} 2$ exceeded the amplitudes at $\mathrm{F} 3$ and $\mathrm{F} 4$ (Fp2 $>\mathrm{F} 3$ and $\mathrm{F} 4$ for the $180^{\circ}$ condition). The task $\times$ angle of difference $\times$ electrode interaction was significant $\left(F_{7119}=6.74, P=0.01, \eta^{2}=\right.$ $=0.28, \phi=1.00)$. Under $0^{\circ}$ condition, the response amplitudes in the delayed task were smaller than the amplitudes during the simultaneous task at F4, C4, and $\mathrm{P} 4$ (delayed $<$ simultaneous at F4, C4, and $\mathrm{P} 4$ for the $0^{\circ}$ condition). The response amplitudes under $0^{\circ}$ condition at $\mathrm{Fp} 2$ in the delayed task were greater than the respective indices for the $180^{\circ}$ condition $\left(0^{\circ}>\right.$ $180^{\circ}$ at Fp 2 in the delayed task). For the simultaneous task, the response amplitudes for the $0^{\circ}$ condition were greater than the amplitudes under $180^{\circ}$ condition at $\mathrm{Fp} 2, \mathrm{~F} 4$, and $\mathrm{C} 4\left(0^{\circ}>180^{\circ}\right.$ at $\mathrm{Fp} 2, \mathrm{~F} 4$, and $\mathrm{C} 4$ during the simultaneous task). For the delayed task, the amplitudes of the responses at $\mathrm{Fp} 2$ for the $0^{\circ}$ and $180^{\circ}$ conditions were higher than those at $\mathrm{F} 3$ and $\mathrm{F} 4\left(\mathrm{Fp} 2>\mathrm{F} 3\right.$ and $\mathrm{F} 4$ for the $0^{\circ}$ and $180^{\circ}$ conditions during the delayed task). Under $0^{\circ}$ condition in the simultaneous task, the amplitudes at $\mathrm{Fp} 2$ were greater than those at Fp1, F3, C3, and P3 (Fp2 > Fp1, F3, C3, and $\mathrm{P} 3$ for the $0^{\circ}$ condition in the simultaneous task). The response amplitudes at F4 were higher than the respective values at $\mathrm{F} 3$ and $\mathrm{P} 3$ ( $\mathrm{F} 4>\mathrm{F} 3$ and $\mathrm{P} 3$ for the $0^{\circ}$ condition during the simultaneous task).

For the $\alpha 2$ subrhythm, the main effect of the electrode position was significant $\left(F_{7,119}=6.20\right.$, $\left.P=0.01, \eta^{2}=0.27, \phi=1.00\right)$, with the amplitudes of the responses at $\mathrm{Fp} 2$ being greater than the respective amplitudes at F3, P3, and P4 (Fp2 > F3, P3, and P4). The angle of difference $\times$ electrode interaction was significant $\left(F_{7,119}=2.66, P=0.01, \eta^{2}=0.14, \phi=.89\right)$. The response amplitudes at Fp2 under $0^{\circ}$ condition were higher than the amplitudes for the $180^{\circ}$ condition $\left(0^{\circ}>180^{\circ}\right.$ at Fp2), and the amplitudes at $\mathrm{Fp} 2$ for the $0^{\circ}$ condition were higher than the response amplitudes at Fp1, F3, P3, and P4 (Fp2 > Fp1, F3, P3, and P4 for the $0^{\circ}$ condition).

The main effect of the electrode location in the $\beta 1$ band was significant $\left(F_{7.119}=6.70, P=0.01, \eta^{2}=0.28\right.$, $\phi=1.00)$, with the amplitudes of the responses at Fp2 being larger than the respective values at P3 (Fp2 > $>$ P3).

For the $\beta 2$ subrange, the main effect of the electrode site was significant $\left(F_{7,119}=8.94, P=0.01, \eta^{2}=0.35\right.$, $\phi=1.00)$. The response amplitudes at P3 were smaller than the amplitudes at Fp1, F3, and F4 (P3 < Fp1, $\mathrm{F} 3$, and F4), and the amplitudes at P4 were smaller than those at $\mathrm{C} 4(\mathrm{P} 4<\mathrm{C} 4)$. The angle of difference $\times$ $\times$ electrode interaction was significant $\left(F_{7,119}=3.57\right.$, $\left.P=0.01, \eta^{2}=0.17, \phi=0.97\right)$. Under $0^{\circ}$ condition, the response amplitudes at $\mathrm{P} 3$ were smaller than those at $\mathrm{Fp} 1$ and F3 (P3 < Fp1 and F3 for the $0^{\circ}$ condition), and the amplitudes at $\mathrm{P} 4$ were smaller than the respective indices at $\mathrm{C} 4\left(\mathrm{P} 4<\mathrm{C} 4\right.$ for the $0^{\circ}$ condition). Under 
$180^{\circ}$ condition, the response amplitudes at $\mathrm{P} 3$ were smaller than those at Fp1, F3, F4, and C4 (P3 < $<\mathrm{Fp} 1, \mathrm{~F} 3, \mathrm{~F} 4$, and $\mathrm{C} 4$ for the $180^{\circ}$ condition), and the amplitudes at $\mathrm{P} 4$ were smaller than the amplitudes at $\mathrm{C} 4\left(\mathrm{P} 4<\mathrm{C} 4\right.$ for the $180^{\circ}$ condition).

Correlation between the Reaction Time and Parameters of EEG waves. The reaction times and response amplitudes for each EEG electrode were analyzed separately for the four frequency ranges $(\alpha 1, \alpha 2, \beta 1$, and $\beta 2)$ using a Pearson correlation approach (Table 1). The results for the simultaneous task indicated that $\mathrm{C} 4(r[18]=-0.47, P=0.05)$ and P4 $(r[18]=-0.61, P=0.01)$ were characterized by lower response amplitudes within the $\beta 2$ band for the $0^{\circ}$ condition within the $\beta 2$ band for the $0^{\circ}$ condition associated with shorter reaction times. In contrast, Fp1 $(r[18]=0.49, P=0.03)$ and Fp2 $(r[18]=0.49$, $P=0.04)$ demonstrated higher response amplitudes within the $\alpha 1$ band for the $180^{\circ}$ condition significantly associated with shorter reaction times.

\section{DISCUSSION}

We examined the effects of observation timing (delayed or simultaneous) and of the cognitive loading of congruence judgments of two poses of an image of a 3D object by measuring the judgment reaction time and parameters of EEG waves. Results of the reaction time analysis showed that when the angle of difference between the two poses was $0^{\circ}$ (frontfront or back-back), participants responded noticeably faster compared to the situation where the angle was $180^{\circ}$. In addition, the reaction times during the delayed observation task were shorter than those in the simultaneous task. These results are comparable to those found in studies on mental rotation [e.g., 3, 4], although when the angle of difference between the two poses was $0^{\circ}$, participants were able to make their judgments without a necessity to mentally rotate the image. In contrast, judgments made under $180^{\circ}$ condition required participants to compare the images by reversing the right vs. left or rotating the image by $180^{\circ}$. Assuming that mental rotation was involved [e.g., 3, 4], it seemed that the existence or nonexistence of the process of mental rotation induced the reaction time differences between the judgments for the two angle conditions. On the other hand, there were also reaction time differences between the two observation tasks. This might be obvious because certaing processing of different visual information was required depending on the task type (delayed or simultaneous). Judging the simultaneous task might require participants to perform on-line processing or dual-processing, which combines encoding the imagery to a representation and comparing the two poses. At the same time, judging the delayed task might require participants to encode the imagery to a representation when observing the first pose and then using this memorized image for comparison when observing the second pose.

The EEG wave analysis indicated that the right hemisphere (that is involved in spatial manipulation of visual information) was activated under $180^{\circ}$ condition and the delayed task. This could occur because activation of the decision-making processes decayed the response amplitude within the $\alpha$ band, and because the frontal lobe, functioning of which is related to working memory, was activated during the congruence judgments of the two poses. Furthermore, the results of correlation analysis between the reaction times and EEG waves indicated that, if the participant responded faster during the simultaneous task, the amplitudes of the responses at $\mathrm{C} 4$ and $\mathrm{P} 4$ within the $\beta 2$ band became greater when the angle of difference of the two poses was $0^{\circ}$. On the other hand, if the response time was smaller when the angle of difference of the two poses was $180^{\circ}$, the amplitudes of the responses at $\mathrm{Fp} 1$ and Fp2 in the $\alpha 1$ band became smaller. These results support the statement that the frontal region (Fp1 and Fp2) becomes active when processing of rotation of an object is performed or when the direction of an object is inverted from left to right [7]. The right hemisphere becomes active when observing images are presented in a delayed manner $[8,9]$. One feature of our results showing that the response amplitudes at C4 and P4 became higher if the response was faster and when the two poses were presented in the same direction may be related to the use of egocentric or allocentric images. The mental rotation abilities in individuals with time-space synesthesia suggest that the parietal lobe areas that process the representations of temporal sequences and visuo-spatial imagery are connected with each other [10]. Additionally, egocentric sensory representations are formated in the parietal region [11]. Reports by Brang et al. [10] and Dhindsa et al. [11] may indicate that observing two postures at the same angle leads to the occurrence of egocentric sensory representations, thus activating the parietal region. 
A limitation of our study is that our tasks were recognition ones. Other essential knowledge might be gained by examining the compatibility between the model and the participant using anatomical matching tasks in future studies.

All test procedures were in accordance with the institutional and national ethical standards mentioned by the responsible Committee on human experimentation and with the Helsinki Declaration of 1975, as revised in 2000 (5).

This study was conducted after obtaining approval from the Doshisha University Ethics Committee for Scientific Research Involving Human Subjects. In addition, all participants provided informed consent by signing a consent form.

The author, T. Ishikura, confirms the absence of any conflict related to the commercial or financial problems and to the relations with organizations or persons, which could in any way be associated with the investigation.

\section{T. Іиикура ${ }^{1}$}

ЗВ' ЯЗОК МІЖ ЧАСОМ РЕАКЦІЇ ТА ПАРАМЕТРАМИ ЕЕГ У ПЕРЕБІГУ ВИРІШЕННЯ ПИТАННЯ ПРО ВІДПОВІДНІСТЬ ДВОХ ЗОБРАЖЕНЬ ТЕСТ-МОДЕЛІ, ПРЕДСТАВЛЕНИХ ОДНОЧАСНО АБО 3 ЗАТРИМКОЮ

\author{
${ }^{1}$ Університет Дошіша, Кіотанабе, Кіото (Японія). \\ $\mathrm{P}$ е 3 ю м е
}

Ми досліджували, яким чином вирішення питання про ідентичність/неідентичність поз тест-фігур, зображення яких представлялись одночасно або з часовою затримкою, впливає на латентний період реакції тестованого суб'єкта та параметри ЕЕГ. 18 студентам університету пропонували «затримане» тест-завдання, в якому тест-об'єкт (зображення антропоморфної фігури, ляльки) пред'являвся на 3 с, після чого із затримкою пред'являлося друге зображення, або «одночасне» завдання, в якому два зображення ляльок пред'являлись одночасно на двох половинах екрану монітора. Тест-зображення ляльок показувалося спереду або ззаду (кути 0 або 180 град). Тестованим пропонувалося максимально точно та швидко вирішити, чи ідентичні дані зображення; при цьому вимірювали час реакції. Сигнали ЕЕГ відводили від локусів Fp1, Fp2, F3, F4, C3, C4, Р3 та P4. Виявилося, що час реакції при реалізації «затримано- го» завдання був коротшим, ніж такий для «одночасного» завдання, і що цей показник для умови 0 град був меншим, ніж відповідне значення для умови 180 град. Амплітуди ЕЕГ у відведеннях Fp1 і Fp2 були вищими, ніж такі в інших відведеннях. ЕЕГ-відповіді в альфа1-субдіапазоні в правій півкулі в «затриманому» тесті для умови 180 град були меншими, ніж аналогічні відповіді в інших відведеннях. Подібні результати вказують на те, що активність у фронтальній зоні правої півкулі асоційована з прийняттям рішення щодо відповідності або невідповідності зображень у завданнях, пов'язаних із встановленням просторового збігу.

\section{REFERENCES}

1. P. McCullagh and M. Weiss, "Modeling: considerations for motor skill performance and psychological responses," in: Handbook of Sport Psychology, R. N. Singer, H. A. Hausenblas, and C. M. Janelle (eds.), John Wiley and Sons, New York (2001), pp. 205-238.

2. T. Ishikura and K. Inomata, "Effects of angle of modeldemonstration on learning of motor skill," Percept. Mot. Skills, 80, 651-658 (1995).

3. R. N. Shepard and J. Metzler, "Mental rotation of threedimentional objects," Science, 171, 701-703 (1971).

4. M. Heil, J. Bajrić, F. Rösler, and E. Hennighausen, “A rotation after effect changes both the speed and the preferred direction of mental rotation," J. Exp. Psychol. Human Percept. Perform., 23, 681-692 (1997).

5. D. L. Weeks, A. K. Hall, and L. P. Anderson, "A comparison of imitation strategies in observational learning of action patterns," J. Mot. Behav., 28, No. 4, 348-358 (1996).

6. J. R. Richardson and T. D. Lee, "The effects of proactive and retroactive demonstrations on learning signed letters," Acta Psychol., 101, 79-90 (1999).

7. M. Heil, "The functional significance of ERP effects during mental rotation," Psychophysiology, 39, 535-545 (2002).

8. B. Krüger, M. Bischoff, C. Blecker, et al., "Parietal and premotor cortices: activation reflects imitation accuracy during observation, delayed imitation and concurrent imitation," NeuroImage, 100, 39-50 (2014).

9. K. Stefan, J. Classen, P. Celnik, and L. G. Cohen, "Concurrent action observation modulates practice-induced motor memory formation," Eur. J. Neurosci., 27, 730-738 (2008).

10. D. Brang, L. E. Miller, M. McQuire, et al., "Enhanced mental rotation ability in time-space synesthesia," Cogn. Process., 14, 429-434 (2013).

11. K. Dhindsa, V. Drobinin, J. King, et al., "Examining the role of the temporo-parietal network in memory, imagery, and viewpoint transformations," Front. Human Neurosci., 8, 709 (2014). 